\title{
Alkyl and alkylidene imido cyclopentadienyl tungsten complexes
}

\author{
Sergio Acebrón, Mikjail V. Galakhov, Pilar Gómez-Sal ${ }^{1}$, Avelino Martín ${ }^{1}$, Pascual Royo *, \\ Amelio Vázquez de Miguel \\ Departamento de Química Inorgánica, Universidad de Alcalá, Campus Universitario, E-28871 Alcalá de Henares, Spain
}

Received 15 May 1998

\begin{abstract}
This paper reports the alkylation of the cyclopentadienyl imido tungsten complexes $\left[\mathrm{WCp}^{\prime}\left(\mathrm{N}^{t} \mathrm{Bu}^{\mathrm{B}}\right) \mathrm{Cl}_{3}\right]\left(\mathrm{Cp}^{\prime}=\eta^{5}-\mathrm{C}_{5} \mathrm{H}_{5}\right.$, $\left.\eta^{5}-\mathrm{C}_{5} \mathrm{Me}_{5}\right)$ with $\beta$-hydrogen containing alkyl groups to render halo alkyl and trialkyl complexes $\left[\mathrm{WCp}^{\prime}\left(\mathrm{N}^{t} \mathrm{Bu}\right) \mathrm{Cl}_{3-n} \mathrm{R}_{n}\right](\mathrm{R}=\mathrm{Et}$, $n$-Pr). Thermal decomposition of the trialkyl compounds gives the alkylidene derivatives $\left[\mathrm{WCp}^{\prime}\left(\mathrm{N}^{t} \mathrm{Bu}\right)(\mathrm{CHR})\left(\mathrm{CH}_{2} \mathrm{R}\right)\right](\mathrm{R}=\mathrm{Me}$, Et) by $\alpha$-hydrogen elimination. All of the compounds were characterized by NMR spectroscopy and the molecular structure of $\left[\mathrm{W}\left(\eta^{5}-\mathrm{C}_{5} \mathrm{Me}_{5}\right)\left(\mathrm{N}^{t} \mathrm{Bu}\right) \mathrm{Et} \mathrm{t}_{3}\right]$ was determined by X-ray diffraction methods. (C) 1999 Elsevier Science S.A. All rights reserved.
\end{abstract}

Keywords: Alkyl; Alkylidene; Imido; Tungsten

\section{Introduction}

High valent molybdenum and tungsten compounds have found important applications as catalysts in various industrial processes related to olefin metathesis [1] and ring opening metathesis polymerization [2], in which intermediate alkylidene moieties are readily formed particularly in the presence of stabilizing alkoxo and imido ligands. Imido molybdenum and tungsten complexes have also been used as model catalysts for the ammoxidation of olefins [3]. For all these reasons the chemistry of transition-metal imido complexes has been extensively developed in the past 5 years and continues to expand [4]. We have lately reported the isolation of several $\eta^{5}$-cyclopentadienyl imido complexes of Group 5 and 6 metals in high

\footnotetext{
* Corresponding author. Tel.: + 34-1-8854-765; fax: + 34-1-8854683.

E-mail address: proyo@inorg.alcala.es (P. Royo)

${ }^{1} \mathrm{X}$-ray diffraction studies.
}

yields [5]. Alkyl derivatives of chloro diimido [6] and trichloro imido [5a,7] cyclopentadienyl molybdenum and tungsten compounds, usually without $\beta$-hydrogen atoms, have been reported. They provide easy access to alkylidene compounds by $\alpha$-hydrogen abstraction followed by reductive elimination of alkanes which have been shown to be effective metathesis catalysts [8]. We have recently reported the isolation of tungsten alkylidene compounds [WCp* $\left.\left(\mathrm{N}^{t} \mathrm{Bu}\right)(=\mathrm{CHR})\left(\mathrm{CH}_{2} \mathrm{R}\right)\right](\mathrm{R}=$ $\left.\mathrm{H}, \mathrm{Ph}, \mathrm{SiMe}_{3}\right)$ and $\left.\left[\mathrm{WCp}^{*}\left(\mathrm{~N}^{t} \mathrm{Bu}\right)(=\mathrm{CHSiMe})_{3}\right) \mathrm{Cl}\right]$ [9] and were interested in studying the behaviour of related compounds with $\beta$-hydrogen containing alkyl groups. Preferential $\alpha$ - against $\beta$-elimination has been reported [10] and the catalytic activity of trans[WOCl ${ }_{2}\left(\mathrm{O}-2,6-\mathrm{Br}_{2} \mathrm{C}_{6} \mathrm{H}_{3}\right)_{2}$ ] in the presence of $\mathrm{PbEt}_{4}$ has been explained [11] on the basis of the intermediate formation of the ethylidene complex by $\alpha$-hydrogen elimination. We report here the results of our studies of the alkylation of $\left[\mathrm{WCp}^{\prime}\left(\mathrm{N}^{t} \mathrm{Bu}\right) \mathrm{Cl}_{3}\right]\left(\mathrm{Cp}^{\prime}=\eta^{5}-\mathrm{C}_{5} \mathrm{H}_{5}\right.$, $\left.\eta^{5}-\mathrm{C}_{5} \mathrm{Me}_{5}\right)$ using ethyl and $n$-propyl alkylating agents, the X-ray crystal structure of the triethyl complex $\left[\mathrm{W}\left(\eta^{5}-\mathrm{C}_{5} \mathrm{Me}_{5}\right)\left(\mathrm{N}^{t} \mathrm{Bu}\right) \mathrm{Et}_{3}\right]$ and the thermal activation of the resulting tungsten alkyls. 


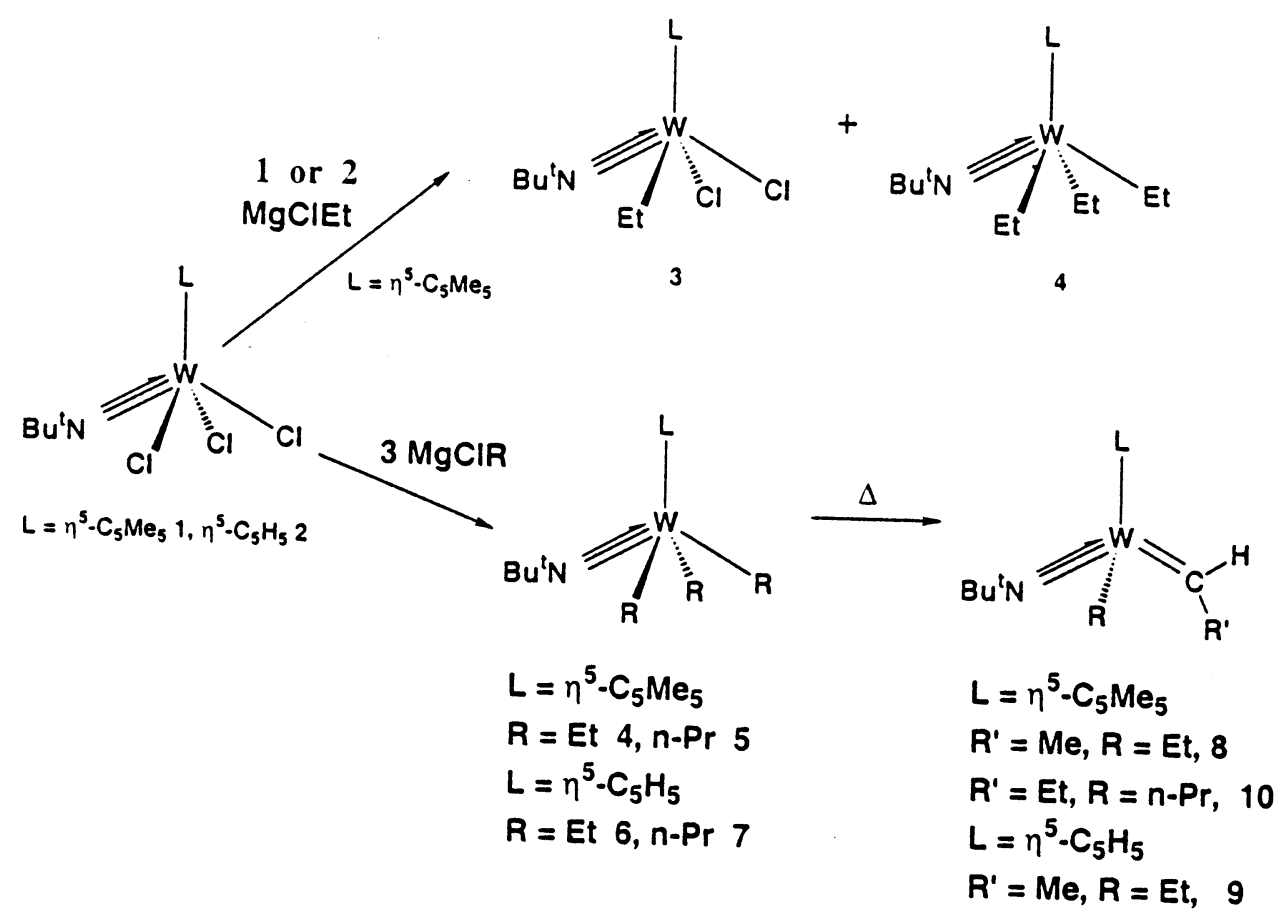

Scheme 1.

\section{Results and discussion}

\subsection{Alkylation reactions}

Alkylation of the trichloro tungsten complex [W( $\eta^{5}$ $\left.\mathrm{C}_{5} \mathrm{Me}_{5}\right)\left(\mathrm{N}^{t} \mathrm{Bu}\right) \mathrm{Cl}_{3}$ ] (1) prepared as reported in detail previously [5a], with $\mathrm{MgClEt}$ was studied using varying molar ratios. Addition of one equivalent of the alkylating agent to a toluene solution of the complex gave an oily orange residue which contained a mixture of various components as evidenced by its ${ }^{1} \mathrm{H}-\mathrm{NMR}$ spectrum from which the triethyl complex $\left[\mathrm{W}\left(\eta^{5}-\mathrm{C}_{5} \mathrm{Me}_{5}\right)\right.$ $\left(\mathrm{N}^{t} \mathrm{Bu}\right) \mathrm{Et}_{3}$ ] (4) was recovered as a yellow crystalline solid after extraction into cold pentane. The resulting pale-yellow residue contains a mixture of excess starting material together with the monoalkylated compound cis $-\left[\mathrm{W}\left(\eta^{5}-\mathrm{C}_{5} \mathrm{Me}_{5}\right)\left(\mathrm{N}^{t} \mathrm{Bu}\right) \mathrm{Cl}_{2} \mathrm{Et}\right] \quad$ (3) characterized by NMR spectroscopy. The initial mixture also contained the trans-3 stereoisomer identified by the unique methylenic $\mathrm{CH}_{2}-\mathrm{Me}$ quartet observed at $\delta 2.40$ in the ${ }^{1} \mathrm{H}-\mathrm{NMR}$ spectrum of the oily residue, which disappeared on manipulation probably due to its isomerization to the cis-3 isomer favoured by the strong transeffect of the imido ligand. Formation of $\mathbf{4}$ when a deficiency of the alkylating agent is present demonstrates that the alkylation of any partially alkylated species is more rapid than that of the starting compound. The monoethyl complex cis-3 could not be obtained free of the starting complex as both exhibited similar solubility and repeated recrystallization from toluene resulted only in a $6 / 1$ molar ratio of both compounds, cis-3 being the major component.

The same behaviour was observed when the reaction was carried out adding two equivalents of the alkylating agent leading to a mixture which contained $\mathbf{4} /$ cis $-\mathbf{3}$ in a molar ratio slightly higher than $1 / 1$ and a smaller amount of the starting trichloro complex. Formation of the diethyl complex was never observed. The triethyl complex 4 was the only component formed and recovered in a $70 \%$ yield after recrystallization when three equivalents of the alkylating agent were used (Scheme $1)$.

An analogous reaction of $\left[\mathrm{W}\left(\eta^{5}-\mathrm{C}_{5} \mathrm{Me}_{5}\right)\left(\mathrm{N}^{t} \mathrm{Bu}\right) \mathrm{Cl}_{3}\right] \mathbf{1}$ with three equivalents of $\mathrm{MgCl}(n-\mathrm{Pr})$ allowed the trialkylated complex $\left[\mathrm{W}\left(\eta^{5}-\mathrm{C}_{5} \mathrm{Me}_{5}\right)\left(\mathrm{N}^{t} \mathrm{Bu}\right)(n-\mathrm{Pr})_{3}\right] 5$ to be isolated as a pale-yellow crystalline solid in a $65 \%$ yield after recrystallization from pentane. Partially alkylated compounds were probably also formed when one or two equivalents of the alkylating agent were used, although we were not able to identify them as single components in the resulting mixtures.

The reaction of $\left[\mathrm{W}\left(\eta^{5}-\mathrm{C}_{5} \mathrm{H}_{5}\right)\left(\mathrm{N}^{t} \mathrm{Bu}\right) \mathrm{Cl}_{3}\right] 2$ (prepared by a previously reported method [5a]) with ethyl and $n$-propyl magnesium chloride also gave unresolvable mixtures of alkylated compounds whereas the related trialkyl complexes $\left[\mathrm{W}\left(\eta^{5}-\mathrm{C}_{5} \mathrm{H}_{5}\right)\left(\mathrm{N}^{t} \mathrm{Bu}\right) \mathrm{R}_{3}\right](\mathrm{R}=\mathrm{Et} \mathbf{6}$, $n$-Pr 7) resulted in unique components when three equivalents of the alkylating agent were used. However 6 and 7 could only be characterized in solution by ${ }^{1} \mathrm{H}-\mathrm{NMR}$ spectroscopy because any attempt made to 


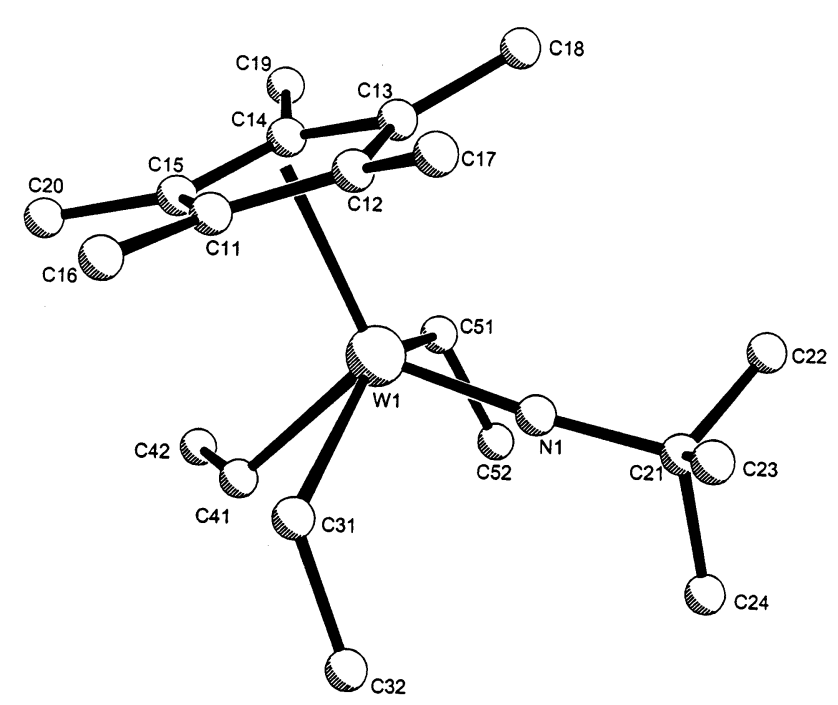

Fig. 1. PLUTO diagram of the molecular structure of $\left[\mathrm{W}\left(\eta^{5}\right.\right.$ $\left.\left.\mathrm{C}_{5} \mathrm{Me}_{5}\right)\left(\mathrm{N}^{t} \mathrm{Bu}\right) \mathrm{Et}_{3}\right]$ 4; the hydrogen atoms are omitted for the sake of clarity.

record ${ }^{13} \mathrm{C}$-NMR spectra or to recover them as solids by evaporation of the solvent resulted in their decomposition to give unidentified products.

\subsection{IR and NMR spectroscopy}

The two triethyl tungsten complexes $\mathbf{4}$ and $\mathbf{6}$ showed two IR absorption bands between 1263 and $1211 \mathrm{~cm}^{-1}$ due to the reported [4a] combination of the $\mathrm{M}=\mathrm{N}$ and $\mathrm{N}-\mathrm{C}$ stretching vibrations whereas absorptions due to $\mathrm{W}-\mathrm{Cl}$ bonds were observed between 400 and $200 \mathrm{~cm}^{-1}$ in the partially alkylated cis-3 complex.

The cis disposition of the imido and the ethyl ligands in complex cis-3 was shown by the chiral character of the metal center which is responsible for the $\mathrm{ABC}_{3}$ spin system of the ethyl group, in contrast with the $A_{2} B_{3}$ spin system observed for trans-3 (see Section 3).

The ${ }^{1} \mathrm{H}-\mathrm{NMR}$ spectra of the triethyl $\mathbf{4}$ and $\mathbf{6}$ and tri- $n$-propyl complexes $\mathbf{5}$ and $\mathbf{7}$ show the expected (two) types of alkyl groups in a 1:2 molar ratio. They exhibit a spectral behaviour consistent with $\mathrm{A}_{2} \mathrm{~B}_{3}$ (trans-ethyl), $\mathrm{ABC}_{3} \quad$ (cis-ethyl), $\quad \mathrm{A}_{2} \mathrm{~B}_{2} \mathrm{C}_{3} \quad$ (trans- $n$-propyl) and $\mathrm{ABCDE}_{3}$ (cis-n-propyl) spin systems, respectively (see Section 3). The ${ }^{13} \mathrm{C}-\mathrm{NMR}$ spectra for $\mathbf{4}$ and $\mathbf{5}$ confirmed these assignments and showed a remarkable shielding $(\Delta \delta=\delta$ trans $-\delta$ cis $)$ trans $-\beta$-effect $(-6.1 \mathrm{ppm}$ for $\mathbf{4}$ and $-6.4 \mathrm{ppm}$ for 5) and a very small $\alpha$-effect $(-1.9 \mathrm{ppm}$ for 4 and $-1.3 \mathrm{ppm}$ for 5 ) of the imido ligand.

In addition two singlets were observed, one for the ${ }^{t} \mathrm{Bu}$ and one for the methyl-cyclopentadienyl groups for all of these compounds.

\subsection{X-ray molecular structure of complex 4}

A diagram of the molecular structure of $\mathbf{4}$ is shown in Fig. 1 and selected bond distances and angles are given in Table 1.

If the centroid of the cyclopentadienyl ligand is viewed as occupying one coordination site, the geometry about tungsten in this complex is close to being square pyramidal with the four positions of the basal plane occupied by the $\mathrm{N} 1$ atom of the imido group and the three carbon atoms of the ethyl substituents C31, $\mathrm{C} 41$ and C51. The imido group shows an almost linear disposition with a W1-N1-C21 angle of $174.6(7)^{\circ}$ and a very short $\mathrm{W} 1-\mathrm{N} 1$ triple bond distance $(1.727(7) \AA)$ indicative of the $\mathrm{sp}$ hybridized nitrogen atom of a four-electron donor ligand which completes the 18-electron count for the metal center. The W-ring centroid and the $\mathrm{W} 1-\mathrm{N} 1$ distances are comparable to those in other tungsten imido complexes such as $\left[\mathrm{W}\left(\eta^{5}\right.\right.$ $\left.\mathrm{C}_{5} \mathrm{Me}_{5}\right)\left(\mathrm{N}^{t} \mathrm{Bu}\right) \mathrm{Cl}_{3}$ ] [5a]. The most significant feature of this structure is the orientation of the ethyl group trans to the imido ligand which shows a W1-C41 distance slightly longer $(2.249(9) \AA)$ than the other two located in cis-positions (2.228(9) and 2.216(9) $\AA$ ), revealing the stronger trans- effect of this ligand. Moreover, the $\mathrm{W} 1-\mathrm{C} 41-\mathrm{C} 42$ angle for the trans-ethyl group is significantly more opened $\left(126.0(6)^{\circ}\right)$ than the corresponding

Table 1

Selected bond lengths $(\AA)$ and angles $\left(^{\circ}\right)$ for $\mathbf{4}^{\mathrm{a}}$

\begin{tabular}{lllll}
\hline $\begin{array}{l}\text { Bond lengths } \\
\mathrm{W}(1)-\mathrm{N}(1)\end{array}$ & $1.727(7)$ & $\mathrm{W}(1)-\mathrm{C}(51)$ & $2.216(9)$ & $\mathrm{W}(1)-\mathrm{C}(31)$ \\
$\mathrm{W}(1)-\mathrm{C}(41)$ & $2.249(9)$ & $\mathrm{N}(1)-\mathrm{C}(21)$ & $1.468(11)$ & $\mathrm{C}(31)-\mathrm{C}(32)$ \\
$\mathrm{C}(41)-\mathrm{C}(42)$ & $1.553(12)$ & $\mathrm{C}(51)-\mathrm{C}(52)$ & $1.501(13)$ & $\mathrm{W}(1)-\mathrm{Cp} \mathrm{p}^{*}(1)$ \\
Bond angles & & & & $1.533(13)$ \\
$\mathrm{N}(1)-\mathrm{W}(1)-\mathrm{C}(31)$ & $87.6(3)$ & $\mathrm{N}(1)-\mathrm{W}(1)-\mathrm{C}(41)$ & $120.4(3)$ & \\
$\mathrm{N}(1)-\mathrm{W}(1)-\mathrm{C}(51)$ & $86.9(3)$ & $\mathrm{C}(51)-\mathrm{W}(1)-\mathrm{C}(31)$ & $142.1(4)$ & \\
$\mathrm{C}(51)-\mathrm{W}(1)-\mathrm{C}(41)$ & $77.3(3)$ & $\mathrm{C}(31)-\mathrm{W}(1)-\mathrm{C}(41)$ & $73.3(3)$ & \\
$\mathrm{C}(21)-\mathrm{N}(1)-\mathrm{W}(1)$ & $174.6(7)$ & $\mathrm{C}(32)-\mathrm{C}(31)-\mathrm{W}(1)$ & $117.5(6)$ & \\
$\mathrm{C}(42)-\mathrm{C}(41)-\mathrm{W}(1)$ & $126.0(6)$ & $\mathrm{C}(52)-\mathrm{C}(51)-\mathrm{W}(1)$ & $117.2(6)$ & \\
$\mathrm{Cp} *(1)-\mathrm{W}(1)-\mathrm{N}(1)$ & 127.9 & $\mathrm{Cp} *(1)-\mathrm{W}(1)-\mathrm{C}(31)$ & 105.8 & \\
$\mathrm{Cp} *(1)-\mathrm{W}(1)-\mathrm{C}(41)$ & 111.7 & $\mathrm{Cp} *(1)-\mathrm{W}(1)-\mathrm{C}(51)$ & 107.1 &
\end{tabular}

\footnotetext{
${ }^{\text {a }} \mathrm{Cp} *(1)$ is the centroid of the cyclopentadienyl ring.
} 
angles (117.5(6) and $\left.117.2(6)^{\circ}\right)$ for the other two ethyl groups with essentially $\mathrm{sp}^{3}$ carbon atoms; the presence of an $\alpha$-agostic interaction, which is the first step of the $\alpha$-elimination process, could not be detected.

\subsection{Thermal activation of the alkyl tungsten complexes}

Thermal activation of the triethyl and tri- $n$-propyl tungsten complexes 4-6 was studied by heating their $\mathrm{C}_{6} \mathrm{D}_{6}$ solutions in sealed NMR tubes and monitoring their transformations by ${ }^{1} \mathrm{H}-\mathrm{NMR}$ spectroscopy. Formation of the ethylidene complexes $\left[\mathrm{WCp}^{\prime}\left(\mathrm{N}^{t} \mathrm{Bu}\right)\right.$ $\left.(=\mathrm{CHR})\left(\mathrm{CH}_{2} \mathrm{R}\right)\right]\left(\mathrm{Cp}^{\prime}=\eta^{5}-\mathrm{C}_{5} \mathrm{H}_{5}, \mathrm{R}=\mathrm{Me} \mathrm{9} ; \mathrm{Cp}^{\prime}=\eta^{5}-\right.$ $\mathrm{C}_{5} \mathrm{Me}_{5}, \mathrm{R}=\mathrm{Me} \mathrm{8}$, Et 10) resulting from $\alpha$-hydrogen elimination is consistent with the observation of characteristic resonances for the $\mathrm{W}=\mathrm{CHR}$ moiety in the ${ }^{1} \mathrm{H}$ - and ${ }^{13} \mathrm{C}-(\mathbf{8}, \mathbf{1 0})$ NMR spectra (see Section 3).

The triethyl complex $\mathbf{6}$ (with the unsubstituted cyclopentadienyl ligand) is thermally stable for 2 days at temperatures under $90^{\circ} \mathrm{C}$ but is slowly transformed, with elimination of ethane, when heated at $90^{\circ} \mathrm{C}$, the reaction being complete after 1 day to give the ethylidene complex [WCp $\left(\mathrm{N}^{t} \mathrm{Bu}\right)(=\mathrm{CHMe})-$ $\left.\left(\mathrm{CH}_{2} \mathrm{Me}\right)\right]$ 9. Similar treatment of complex 4 (with the permethylated cyclopentadienyl ring) revealed that this compound is transformed at lower temperature $\left(45^{\circ} \mathrm{C}\right)$ but its decomposition is slower than that of complex $6,80 \mathrm{~h}$ being required to complete its transformation to give $\left[\mathrm{WCp}^{*}\left(\mathrm{~N}^{t} \mathrm{Bu}\right)(=\mathrm{CHMe})\left(\mathrm{CH}_{2} \mathrm{Me}\right)\right] \mathbf{8}$. When heated at temperatures higher than $50^{\circ} \mathrm{C}$ the reaction was faster but the resulting ethylidene complex was always contaminated by other unidentified by-products. In this case, the steric hindrance of the bulkier cyclopentadienyl ligand and its higher donor capacity makes its transformation into the ethylidene compound slower and less selective [10]. Similar treatment of the tri- $n$-propyl complex 5 led to its transformation after $3 \mathrm{~h}$ at $25^{\circ} \mathrm{C}$, although a complete transformation required heating at $40^{\circ} \mathrm{C}$ for $24 \mathrm{~h}$ and was favoured by the presence of sun-light, giving the corresponding $n$-propylidene derivative [WCp* $\left(\mathrm{N}^{t} \mathrm{Bu}\right)$ $\left.(=\mathrm{CHEt})\left(\mathrm{CH}_{2} \mathrm{Et}\right)\right]$ 10. This behaviour is consistent with the known preference for $\alpha-\mathrm{H}$ abstraction in compounds containing larger $\mathrm{C}_{\beta}$ substituents [10].

The ${ }^{1} \mathrm{H}-\mathrm{NMR}$ spectra of complexes $\mathbf{8}, \mathbf{9}$ and $\mathbf{1 0}$ showed the expected signals for the ethylidene proton of the $\mathrm{W}=\mathrm{CHCH}_{3}$ moiety and the diastereotopic methylenic protons for the remaining alkyl group due to the chiral character of the tungsten atom. A NOE experiment $(\mathrm{NOE}=0.58 \%)$ for complex 8 allowed the assignment of the disposition of the ethylidene group with the $\mathrm{H}$ atom oriented in the direction of the cyclopentadienyl ring. All these assignments were confirmed by the ${ }^{13} \mathrm{C}-\left\{{ }^{1} \mathrm{H}\right\}-\mathrm{NMR}$ spectra of $\mathbf{8}$ and $\mathbf{1 0}$ which showed the resonance due to the ethylidene carbon at $\delta 247.4\left({ }^{1} J_{\mathrm{CW}}=167.2 \mathrm{~Hz}\right)$ and $\delta 256.0$ $\left({ }^{1} J_{\mathrm{CW}}=169.1 \mathrm{~Hz}\right.$ ), respectively (see Section 3 ).

\section{Experimental}

\subsection{General methods}

All manipulations were performed under an inert atmosphere of argon using standard Schlenck techniques or a dry box. Solvents used were previously dried and freshly distilled under argon: THF from sodium benzophenone ketyl; toluene from sodium; hexane from sodium-potassium. Unless otherwise stated, reagents were obtained from commercial sources and used as received. The following reagents were synthesized using literature procedures: $\left[\mathrm{W}\left(\eta^{5}\right.\right.$ $\left.\left.\mathrm{C}_{5} \mathrm{Me}_{5}\right]\left(\mathrm{N}^{t} \mathrm{Bu}\right) \mathrm{Cl}_{3}\right]$ and $\left[\mathrm{W}\left(\eta^{5}-\mathrm{C}_{5} \mathrm{H}_{5}\right)\right]\left(\mathrm{N}^{t} \mathrm{Bu} \mathrm{Cl}_{3}\right]$ [5a]. IR spectra were recorded in Nujol mulls between CsI pellets, over the range $4000-200 \mathrm{~cm}^{-1}$ on a PerkinElmer 583 spectrophotometer. ${ }^{1} \mathrm{H}-$ and ${ }^{13} \mathrm{C}-\mathrm{NMR}$ spectra were recorded on a Unity 300 or Unity 500 Plus spectrometer. Chemical shifts, in ppm, are measured relative to residual ${ }^{1} \mathrm{H}$ - and ${ }^{13} \mathrm{C}$ - resonances for benzene- $\mathrm{d}_{6}$ used as the solvent: $7.15\left({ }^{1} \mathrm{H}\right)$ and 128.0 $\left({ }^{13} \mathrm{C}\right)$, and coupling constants are in $\mathrm{Hz} . \mathrm{C}, \mathrm{H}$ and $\mathrm{N}$ analysis were carried out with a Perkin-Elmer $240 \mathrm{C}$ analyzer.

\subsection{Reaction of $\left[W C p^{*}\left(N^{t} B u\right) C l_{3}\right]$ with $\mathrm{MgEtCl}$}

\subsubsection{Molar ratio $1 / 1$}

A $2 \mathrm{M}$ solution of $\mathrm{MgEtCl}$ in THF $(0.53 \mathrm{ml}, 1.06$ mmol) was added to a solution of $\left[\mathrm{WCp}^{*}\left(\mathrm{~N}^{t} \mathrm{Bu}\right) \mathrm{Cl}_{3}\right]$ $(0.53 \mathrm{~g}, 1.06 \mathrm{mmol})$ in toluene $(50 \mathrm{ml})$ cooled to $78^{\circ} \mathrm{C}$. Darkening of the solution was observed when the solution was warmed to room temperature (r.t.). After $16 \mathrm{~h}$ the solution was filtered and the solvent was removed under vacuum to give an oily green residue. This residue was washed with cold pentane and the resulting pale yellow solid was recrystallized from hexane to give a solid which according to its ${ }^{1} \mathrm{H}-\mathrm{NMR}$ spectrum contained a $1 / 1$ mixture of the monoethyl [WCp* $\left(\mathrm{N}^{t} \mathrm{Bu}\right) \mathrm{EtCl}_{2}$ ] $\mathbf{3}$ and the starting complex 1. Repeated recrystallization of this mixture from hexane gave a mixture of $\mathbf{3} / \mathbf{1}$ in a molar ratio of $6 / 1$ with yields lower than $10 \%$. Pure complex 3 could not be isolated and therefore was only characterized by NMR spectroscopy. ${ }^{1} \mathrm{H}-\mathrm{NMR}(\delta \mathrm{ppm}$, $\left.\mathrm{C}_{6} \mathrm{D}_{6}\right): 1.12,2.02,2.57\left(1 \mathrm{H}, 1 \mathrm{H}, 3 \mathrm{H}, \mathrm{CH}_{2} \mathrm{CH}_{3} \mathrm{ABC}_{3}\right.$ spin system: $\left.{ }^{2} J_{\mathrm{HH}}=9.5 \mathrm{~Hz},{ }^{3} J_{\mathrm{HH}}=7.0 \mathrm{~Hz}\right), 1.21(\mathrm{~s}$, $\left.9 \mathrm{H}, \mathrm{NCMe}_{3}\right), 1.72\left(\mathrm{~s}, 15 \mathrm{H}, \mathrm{C}_{5} M e_{5}\right) .{ }^{13} \mathrm{C}-\mathrm{NMR}(\delta$ ppm, $\left.\mathrm{C}_{6} \mathrm{D}_{6}\right): 11.7 \quad\left(\mathrm{C}_{5} M e_{5}\right), 23.0 \quad\left(\mathrm{CH}_{2} \mathrm{CH}_{3}\right), 29.4$ $\left(\mathrm{CMe}_{3}\right), 53.9 \quad\left({ }^{1} J_{\mathrm{CW}}=70.7, \mathrm{CH}_{2} \mathrm{CH}_{3}\right), 72.9\left(\mathrm{CMe}_{3}\right)$, $118.4\left(C_{5} \mathrm{Me}_{5}\right)$. 


\subsubsection{Molar ratio $1 / 3$}

A $2 \mathrm{M}$ solution of $\mathrm{MgClEt}$ in THF $(1.8 \mathrm{ml}, 3.60$ mmol) was added to a toluene $(50 \mathrm{ml})$ solution of $\left[\mathrm{WCp} *\left(\mathrm{~N}^{t} \mathrm{Bu}\right) \mathrm{Cl}_{3}\right](0.60 \mathrm{~g}, 1.20 \mathrm{mmol})$ cooled to $78^{\circ} \mathrm{C}$ and the mixture was stirred for $16 \mathrm{~h}$. The solution was filtered and the solvent removed under vacuum to give a brown oil which was extracted into a $1 / 1$ mixture of toluene/hexane $(2 \times 20 \mathrm{ml})$. The yellow solution was concentrated to ca. $15 \mathrm{ml}$ and cooled to $-40^{\circ} \mathrm{C}$ to give the triethyl complex $\left[\mathrm{WCp}^{*}\left(\mathrm{~N}^{t} \mathrm{Bu}\right) \mathrm{Et}_{3}\right] \mathbf{4}$ as yellow crystals $(0.40 \mathrm{~g}, 0.84$ mmol, $70 \%$ yield). Anal. Calc. for $\mathrm{C}_{20} \mathrm{H}_{39} \mathrm{NW}$ : C, 50.32; H, 8.23; N, 2.93. Found: C, 50.39; H, 8.27; N, 2.94. IR (Nujol mull, $v \mathrm{~cm}^{-1}$ ): 1263 (s), 1211 (s), $1068(\mathrm{~m}), 1023(\mathrm{~m}), 462(\mathrm{w}), 442(\mathrm{w}) .{ }^{1} \mathrm{H}-\mathrm{NMR}(\delta$ ppm, $\left.\mathrm{C}_{6} \mathrm{D}_{6}\right): 1.18,1.77\left(2 \mathrm{H}, 3 \mathrm{H},{ }^{3} J_{\mathrm{HH}}=7.0 \mathrm{~Hz}, \mathrm{~A}_{2} \mathrm{~B}_{3}\right.$ spin system $\mathrm{CH}_{2} \mathrm{CH}_{3}$ trans), 1.22 (s, 9H, $\left.\mathrm{CMe}_{3}\right), 1.42$, $1.53,2.13\left(2 \mathrm{H}, 2 \mathrm{H}, 6 \mathrm{H},{ }^{2} J_{\mathrm{HH}}=10.5 \mathrm{~Hz},{ }^{3} J_{\mathrm{HH}}=7.0\right.$ $\mathrm{Hz}, \mathrm{ABC}_{3}$ spin system $\mathrm{CH}_{2} \mathrm{CH}_{3}$ cis $), 1.57$ (s, $15 \mathrm{H}$, $\left.\mathrm{C}_{5} M e_{5}\right) \cdot{ }^{13} \mathrm{C}-\mathrm{NMR}\left(\delta \mathrm{ppm}, \mathrm{C}_{6} \mathrm{D}_{6}\right): 10.8\left(\mathrm{C}_{5} M e_{5}\right), 16.5$ $\left(\mathrm{CH}_{2} \mathrm{CH}_{3}\right.$ trans $), 22.6\left(\mathrm{CH}_{2} \mathrm{CH}_{3}\right.$ cis $)$, $29.6\left(\mathrm{CMe}_{3}\right)$, $36.0 \quad\left(\mathrm{CH}_{2} \mathrm{CH}_{3}\right.$ trans $), \quad 37.9 \quad\left(\mathrm{CH}_{2} \mathrm{CH}_{3}\right.$ cis $), \quad 70.4$ $\left(C \mathrm{Me}_{3}\right), 115.0\left(C_{5} \mathrm{Me}_{5}\right)$.

\subsection{Reaction of $\left[W_{C}{ }^{*}\left(N^{t} B u\right) C l_{3}\right]$ with $\mathrm{MgCl}(n-\mathrm{Pr})$}

A $2 \mathrm{M}$ diethyl ether solution of $\mathrm{MgCl}(n-\mathrm{Pr})(2.00$ $\mathrm{ml}, 4.00 \mathrm{mmol}$ ) was added to a toluene solution of $\left[\mathrm{WCp} *\left(\mathrm{~N}^{t} \mathrm{Bu}\right) \mathrm{Cl}_{3}\right](0.66 \mathrm{~g}, 1.33 \mathrm{mmol})$. After stirring for $16 \mathrm{~h}$ at $\mathrm{r}$.t. the solution was filtered and the solvent removed under vacuum to give a yellow oil which was recrystallized from pentane to give [WCp* $\left.\left(\mathrm{N}^{t} \mathrm{Bu}\right)(n-\mathrm{Pr})_{3}\right] \mathbf{5}$ as yellow crystals. Yield $65 \%$ $(0.45 \mathrm{~g}, 0.86 \mathrm{mmol})$. Anal. Calc. for $\mathrm{C}_{23} \mathrm{H}_{45} \mathrm{NW}: \mathrm{C}$, 53.18; H, 8.73; N, 2.70. Found: C, 53.03; H, 8.70; N, 2.70. IR (Nujol mull, $v \mathrm{~cm}^{-1}$ ): $1262(\mathrm{~s}), 1211$ (s), $1023(\mathrm{~m}), 383(\mathrm{w}), 347$ (w). ${ }^{1} \mathrm{H}-\mathrm{NMR}\left(\delta \mathrm{ppm}, \mathrm{C}_{6} \mathrm{D}_{6}\right)$ : $1.05,1.71,1.32\left(2 \mathrm{H}, 2 \mathrm{H}, 3 \mathrm{H}, \mathrm{A}_{2} \mathrm{~B}_{2} \mathrm{C}_{3}\right.$ spin system $\mathrm{CH}_{2} \mathrm{CH}_{2} \mathrm{CH}_{3}$ trans), 1.20 (s, 9H, CMe ${ }_{3}$ ), 1.30, 1.44, $2.07,2.18,1.34,\left(2 \mathrm{H}, 2 \mathrm{H}, 2 \mathrm{H}, 2 \mathrm{H}, 6 \mathrm{H}, \mathrm{ABCDE}_{3}\right.$ spin system $\mathrm{CH}_{2} \mathrm{CH}_{2} \mathrm{CH}_{3}$ cis), 1.58 (s, $\left.15 \mathrm{H}, \mathrm{C}_{5} \mathrm{Me}_{5}\right) .{ }^{13} \mathrm{C}-$ $\begin{array}{llllll}\mathrm{NMR} & \left(\delta \quad \mathrm{ppm}, \quad \mathrm{C}_{6} \mathrm{D}_{6}\right): & 11.0 & \left(\mathrm{C}_{5} M e_{5}\right), & 24.0\end{array}$ $\left(\mathrm{CH}_{2} \mathrm{CH}_{2} \mathrm{CH}_{3}\right.$ trans $), 25.4\left(\mathrm{CH}_{2} \mathrm{CH}_{2} \mathrm{CH}_{3}\right.$ trans $), 31.8$ $\left(\mathrm{CH}_{2} \mathrm{CH}_{2} \mathrm{CH}_{3}\right.$ cis $), 29.7\left(\mathrm{CMe}_{3}\right), 23.1 \quad\left(\mathrm{CH}_{2} \mathrm{CH}_{2} \mathrm{CH}_{3}\right.$ cis $), \quad 48.5 \quad\left({ }^{1} J_{\mathrm{CW}}=68.7, \quad \mathrm{CH}_{2} \mathrm{CH}_{2} \mathrm{CH}_{3}\right.$ trans $), \quad 49.8$ $\left({ }^{1} J_{\mathrm{CW}}=65.6, \mathrm{CH}_{2} \mathrm{CH}_{2} \mathrm{CH}_{3}\right.$ cis $), 70.8\left(\mathrm{CMe}_{3}\right), \quad 110.5$ $\left(C_{5} \mathrm{Me}_{5}\right)$.

\subsection{Reaction of $\left[\mathrm{WCp}\left(\mathrm{N}^{t} \mathrm{Bu}\right) \mathrm{Cl}_{3}\right]$ with $\mathrm{MgEtCl}$}

A $2 \mathrm{M}$ solution of $\mathrm{MgEtCl}$ in $\mathrm{THF}(2.1 \mathrm{ml}, 4.20$ mmol) was added to a solution of $\left[\mathrm{WCp}\left(\mathrm{N}^{t} \mathrm{Bu}\right) \mathrm{Cl}_{3}\right]$ $(0.69 \mathrm{~g}, 1.40 \mathrm{mmol})$ in toluene $(50 \mathrm{ml})$ cooled to $78^{\circ} \mathrm{C}$. Darkening of the solution was observed immediately and after $10 \mathrm{~h}$ the solution was filtered and the residue was extracted into pentane $(2 \times 20 \mathrm{ml})$ to give a solution of the triethyl complex [WCp $\left.\left(\mathrm{N}^{t} \mathrm{Bu}\right) \mathrm{Et}_{3}\right]$ 6, which was characterized by its ${ }^{1} \mathrm{H}-$ NMR spectrum. Data of 6: ${ }^{1} \mathrm{H}-\mathrm{NMR}\left(\delta \mathrm{ppm}, \mathrm{C}_{6} \mathrm{D}_{6}\right)$ : $1.10(\mathrm{~s}, 9 \mathrm{H}, \mathrm{CMe}), 1.81,2.60,1.65(2 \mathrm{H}, 2 \mathrm{H}, 6 \mathrm{H}$, $\mathrm{ABC}_{3}$ spin system $\mathrm{CH}_{2} \mathrm{CH}_{3}$ cis), not detected $\left(\mathrm{CH}_{2} \mathrm{CH}_{3}\right.$ trans $), 2.12\left(3 \mathrm{H},{ }^{3} J_{\mathrm{HH}}=7.2 \mathrm{~Hz}, \mathrm{CH}_{2} \mathrm{CH}_{3}\right.$ trans), $5.13\left(\mathrm{~s}, 5 \mathrm{H}, \mathrm{C}_{5} H_{5}\right)$.

\subsection{Reaction of $\left[W C p\left(N^{t} B u\right) C l_{3}\right]$ with $\mathrm{MgCl}(n-P r)$}

A $2 \mathrm{M}$ solution of $\mathrm{MgCl}(n-\mathrm{Pr})$ in $\mathrm{Et}_{2} \mathrm{O}(1.00 \mathrm{ml}$, $2.00 \mathrm{mmol})$ was added to a solution of $\left[\mathrm{WCp}\left(\mathrm{N}^{t} \mathrm{Bu}\right) \mathrm{Cl}_{3}\right](0.28 \mathrm{~g}, 0.66 \mathrm{mmol})$ in toluene $(50$ $\mathrm{ml}$ ). After stirring for $10 \mathrm{~h}$ at r.t. the solution was filtered and the solvent removed under vacuum to give a yellow oil which was characterized as the tri- $n$ propyl complex $\left[\mathrm{WCp}\left(\mathrm{N}^{t} \mathrm{Bu}\right)(n-\mathrm{Pr})_{3}\right]$ 7. ${ }^{1} \mathrm{H}-\mathrm{NMR}(\delta$ ppm, $\left.\mathrm{C}_{6} \mathrm{D}_{6}\right): 1.08$ (s, 9H, $\mathrm{CMe}_{3}$ ), 1.31, ca. 1.6, 2.10 $\left(2 \mathrm{H}, 2 \mathrm{H}, 3 \mathrm{H}, \mathrm{CH}_{2} \mathrm{CH}_{2} \mathrm{CH}_{3}\right.$ trans $), 1.77,2.41,1.23$ $\left(2 \mathrm{H}, 2 \mathrm{H}, 6 \mathrm{H}, \mathrm{CH}_{2} \mathrm{CH}_{2} \mathrm{CH}_{3}\right.$ cis $), 5.13$ (s, $15 \mathrm{H}, \mathrm{C}_{5} \mathrm{H}_{5}$ ).

\subsection{Thermal activation of $\left[W C p^{*}\left(N^{t} B u\right) E t_{3}\right] 4$}

A solution of $4(0.015 \mathrm{~g}, 0.03 \mathrm{mmol})$ in $1 \mathrm{ml}$ of $\mathrm{C}_{6} \mathrm{D}_{6}$ was added to an NMR tube which was then sealed and heated to $45^{\circ} \mathrm{C}$ in an oil bath for $80 \mathrm{~h}$. Elimination of ethane $\left(\begin{array}{ll}\delta & 0.79\end{array}\right)$ and formation of $\left[\mathrm{WCp} *\left(\mathrm{~N}^{t} \mathrm{Bu}\right)(=\mathrm{CHMe}) \mathrm{Et}\right] \mathbf{8}$ were observed by NMR spectroscopy. ${ }^{1} \mathrm{H}-\mathrm{NMR}\left(\delta\right.$ ppm, $\left.\mathrm{C}_{6} \mathrm{D}_{6}\right): 1.22$ (s, 9H, $\left.\mathrm{C} M e_{3}\right), 1.41\left(\mathrm{dqd}, 1 \mathrm{H},{ }^{2} J_{\mathrm{HH}}=10.9 \mathrm{~Hz},{ }^{3} J_{\mathrm{HH}}=7.25\right.$ $\left.\mathrm{Hz},{ }^{4} J_{\mathrm{HH}}=0.5 \mathrm{~Hz}, \quad \mathrm{CH} \mathrm{HCH}_{3}\right), 1.52(\mathrm{dqq}, \quad 1 \mathrm{H}$, ${ }^{2} J_{\mathrm{HH}}=10.9 \mathrm{~Hz}, \quad{ }^{3} J_{\mathrm{HH}}=8.0 \quad \mathrm{~Hz}, \quad{ }^{5} J_{\mathrm{HH}}=0.5 \mathrm{~Hz}$, $\left.\mathrm{CH} \mathrm{HCH}_{3}\right), 1.57$ (s, 15H, C $\left.\mathrm{Ce}_{5}\right), 2.14$ (dd, 3H, $\left.{ }^{3} J_{\mathrm{HH}}=7.25 \mathrm{~Hz},{ }^{3} J_{\mathrm{HH}}=8.0 \mathrm{~Hz}, \mathrm{CH}_{2} \mathrm{CH}_{3}\right), 3.64(\mathrm{dd}$, $\left.3 \mathrm{H},{ }^{3} J_{\mathrm{HH}}=8.15 \mathrm{~Hz},{ }^{5} J_{\mathrm{HH}}=0.5 \mathrm{~Hz}, \mathrm{CHCH}_{3}\right), 9.90$ $\left(\mathrm{qd}, 1 \mathrm{H},{ }^{3} J_{\mathrm{HH}}=8.15 \mathrm{~Hz},{ }^{4} J_{\mathrm{HH}}=0.5 \mathrm{~Hz},{ }^{2} J_{\mathrm{HW}}=3.8\right.$ $\left.\mathrm{Hz}, \mathrm{CHCH}_{3}\right) \cdot{ }^{13} \mathrm{C}-\mathrm{NMR}\left(\delta \mathrm{ppm}\right.$, in $\left.\mathrm{C}_{6} \mathrm{D}_{6}\right): 11.1$ (q, $\left.{ }^{1} J_{\mathrm{CH}}=126.1 \mathrm{~Hz}, \mathrm{C}_{5} M e_{5}\right), 18.2\left(\mathrm{tm},{ }^{1} J_{\mathrm{CH}}=120.7 \mathrm{~Hz}\right.$, $\left.\mathrm{CH}_{2} \mathrm{CH}_{3}\right), 25.4\left(\mathrm{qt},{ }^{1} J_{\mathrm{CH}}=123.2 \mathrm{~Hz},{ }^{2} J_{\mathrm{CH}}=3.9 \mathrm{~Hz}\right.$, $\left.\mathrm{CH}_{2} \mathrm{CH}_{3}\right), 31.9\left(\mathrm{qm},{ }^{1} J_{\mathrm{CH}}=125.7 \mathrm{~Hz}, \mathrm{CMe} e_{3}\right), 36.8(\mathrm{q}$, $\left.{ }^{1} J_{\mathrm{CH}}=124.8 \mathrm{~Hz}, \mathrm{CHCH}_{3}\right), 67.0\left(\mathrm{~m}, C \mathrm{Me}_{3}\right), 109.0(\mathrm{~m}$, $\left.C_{5} \mathrm{Me}_{5}\right), 247.4\left(\mathrm{dq},{ }^{1} J_{\mathrm{CH}}=125.8 \mathrm{~Hz},{ }^{2} J_{\mathrm{CH}}=6.7 \mathrm{~Hz}\right.$, $\left.{ }^{1} J_{\mathrm{CW}}=167.2 \mathrm{~Hz}, \mathrm{CHCH}_{3}\right)$.

\subsection{Thermal activation of $\left[W C p\left(N^{t} B u\right) E t_{3}\right] 6$}

A solution of $6(0.015 \mathrm{~g}, 0.04 \mathrm{mmol})$ in $1 \mathrm{ml}$ of $\mathrm{C}_{6} \mathrm{D}_{6}$ was added to an NMR tube which was then sealed and heated to $90^{\circ} \mathrm{C}$ in an oil bath for $24 \mathrm{~h}$. The ${ }^{1} \mathrm{H}-\mathrm{NMR}$ demonstrated the elimination of ethane $\left(\begin{array}{ll}\delta & 0.79\end{array}\right)$ and formation of the alkylidene complex $\left[\mathrm{WCp}\left(\mathrm{N}^{t} \mathrm{Bu}\right)(=\mathrm{CHMe}) \mathrm{Et}\right]$ 9: ${ }^{1} \mathrm{H}-\mathrm{NMR}\left(\delta \mathrm{ppm}, \mathrm{C}_{6} \mathrm{D}_{6}\right)$ : $1.23\left(\mathrm{~s}, 9 \mathrm{H}, \mathrm{CM} e_{3}\right), 1.92\left(\mathrm{t}, 3 \mathrm{H},{ }^{3} J_{\mathrm{HH}}=7.5 \mathrm{~Hz}\right.$, $\left.\mathrm{CH}_{2} \mathrm{CH}_{3}\right)$, not observed $\left(\mathrm{CH}_{2} \mathrm{CH}_{3}\right), 3.64$ (d, $3 \mathrm{H}$, $\left.{ }^{3} J_{\mathrm{HH}}=8.4 \mathrm{~Hz}, \mathrm{CHCH}_{3}\right), 5.35\left(\mathrm{~s}, 5 \mathrm{H}, \mathrm{C}_{5} H_{5}\right), 10.60$ (c, $\left.1 \mathrm{H},{ }^{3} \mathrm{~J}_{\mathrm{HH}}=8.4 \mathrm{~Hz},=\mathrm{CHCH}_{3}\right)$. 


\subsection{Thermal activation of $\left[W C p^{*}\left(N^{t} B u\right)(n-P r)_{3}\right] 5$}

A solution of $5(0.015 \mathrm{~g}, 0.03 \mathrm{mmol})$ in $1 \mathrm{ml}$ of $\mathrm{C}_{6} \mathrm{D}_{6}$ was added to an NMR tube which was then sealed and heated to $40^{\circ} \mathrm{C}$ in an oil bath for $24 \mathrm{~h}$. Elimination of propane was demonstrated by the ${ }^{1} \mathrm{H}-\mathrm{NMR}$ spectrum $(\delta 0.85 \mathrm{t}, 6 \mathrm{H} ; 1.33 \mathrm{~d}, 2 \mathrm{H})$ leaving a solution of the propylidene derivative $\left[\mathrm{WCp} *\left(\mathrm{~N}^{t} \mathrm{Bu}\right)(=\mathrm{CHEt})(n-\mathrm{Pr})\right] \mathbf{1 0}$. ${ }^{1} \mathrm{H}-\mathrm{NMR}\left(\delta \mathrm{ppm}, \mathrm{C}_{6} \mathrm{D}_{6}\right): 1.279\left(\mathrm{t}, 3 \mathrm{H},{ }^{3} J_{\mathrm{HH}}=7.5 \mathrm{~Hz}\right.$, $\left.\mathrm{CHCH}_{2} \mathrm{CH}_{3}\right), 1.284\left(\mathrm{~s}, 9 \mathrm{H}, \mathrm{CMe}_{3}\right), 1.81(\mathrm{~s}, 15 \mathrm{H}$, $\left.\mathrm{C}_{5} \mathrm{Me}_{5}\right), 2.14,2.30$, ca. $1.25,1.22(1 \mathrm{H}, 1 \mathrm{H} 2 \mathrm{H}, 3 \mathrm{H}$, $\mathrm{ABCDE}_{3}$ spin system $\left.\mathrm{CH}_{2} \mathrm{CH}_{2} \mathrm{CH}_{3}\right), 3.72(\mathrm{dqd}, 1 \mathrm{H}$, ${ }^{2} J_{\mathrm{HH}}=9.5 \mathrm{~Hz},{ }^{3} J_{\mathrm{HH}}=7.5 \mathrm{~Hz}, \quad{ }^{3} J_{\mathrm{HH}}=7.5 \mathrm{~Hz}$, $\left.\mathrm{CHCH} \mathrm{HCH}_{3}\right), 4.13\left(\mathrm{dqd}, 1 \mathrm{H},{ }^{2} J_{\mathrm{HH}}=9.5 \mathrm{~Hz},{ }^{3} J_{\mathrm{HH}}=\right.$ $\left.7.5 \mathrm{~Hz},{ }^{3} J_{\mathrm{HH}}=7.0 \mathrm{~Hz}, \mathrm{CHCH} \mathrm{HCH}_{3}\right), 9.70(\mathrm{dd}, 1 \mathrm{H}$, $\left.{ }^{3} J_{\mathrm{HH}}=7.1 \mathrm{~Hz},{ }^{3} J_{\mathrm{HH}}=7.5 \mathrm{~Hz}, \mathrm{CHCH}_{2} \mathrm{CH}_{3}\right) .{ }^{13} \mathrm{C}-\mathrm{NMR}$ $\left(\delta \mathrm{ppm}, \mathrm{C}_{6} \mathrm{D}_{6}\right): 11.2\left(\mathrm{C}_{5} M e_{5}\right), 18.7\left(\mathrm{CH}_{2} \mathrm{CH}_{2} \mathrm{CH}_{3}\right), 22.5$ $\left(\mathrm{CHCH}_{2} \mathrm{CH}_{3}\right), 29.6\left(\mathrm{CH}_{2} \mathrm{CH}_{2} \mathrm{CH}_{3}\right), 31.8\left(\mathrm{CMe}_{3}\right), 34.8$ $\left(\mathrm{CHCH}_{2} \mathrm{CH}_{3}\right), 44.6\left(\mathrm{CH}_{2} \mathrm{CH}_{2} \mathrm{CH}_{3}\right), 67.5\left(\mathrm{CMe}_{3}\right), 109.0$ $\left(C_{5} \mathrm{Me}_{5}\right), 256.0\left({ }^{1} J_{\mathrm{CW}}=169.1 \mathrm{~Hz}, \mathrm{CHCH}_{2} \mathrm{CH}_{3}\right)$.

\subsection{X-ray structure determination of $\mathbf{4}$}

A yellow crystal of $\left[\mathrm{WCp}^{*}\left(\mathrm{~N}^{t} \mathrm{Bu}\right) \mathrm{Et}_{3}\right] \mathbf{4}$ crystallized from a $1 / 1$ toluene/pentane mixture at $-40^{\circ} \mathrm{C}$ was mounted in a glass capillary, in a random orientation, on an Enraf-Nonius Cad4 four-circle automatic diffractometer with graphite-monochromated $\mathrm{Mo}-\mathrm{K}_{\alpha}$ radiation $(\lambda=0.7073 \AA)$ Crystallographic and experimental details of $\mathbf{4}$ are summarized in Table 2. Data were collected at r.t. Intensities were corrected for Lorentz and polarization effects in the usual manner. No absorption or extinction corrections were made. Intensity measurements were performed by $\omega-\theta$ scans in the range $2^{\circ}<2 \theta<52^{\circ}$.

The structure was solved by direct methods and refined by least squares against $F^{2}$ (SHELXL-97) [12]. Of the 4589 measured reflections, 3999 were independent; $R_{1}=00.041$ and $w R_{2}=0.080$ (for 2258 reflections with $I>2 \sigma(I))$. The values of $R_{1}$ and $w R_{2}$ are defined by $\quad R_{1}=\Sigma|| F_{\mathrm{o}}|-| F_{\mathrm{c}}|| /\left[\Sigma\left|F_{\mathrm{o}}\right|\right] ; \quad w R_{2}=\left\{\left[\Sigma w\left(F_{\mathrm{o}}^{2}-F_{\mathrm{c}}^{2}\right)^{2}\right] /\right.$ $\left.\left[\Sigma w\left(F_{\mathrm{o}}^{2}\right)^{2}\right]\right\}^{1 / 2}$, where $w=1 /\left[\sigma^{2}\left(F_{\mathrm{o}}\right)^{2}+(0.0433 P)^{2}\right], P=$ $\left(F_{\mathrm{o}}^{2}+2 F_{\mathrm{c}}^{2}\right) / 3$ and $\sigma$ was obtained from counting statistics. All non-hydrogen atoms were refined anisotropically and the hydrogen atoms were introduced in the last cycle of refinement from geometrical calculations and refined using a riding model with thermal parameters fixed at $U=0.08 \AA^{2}$.

\section{Conclusions}

New cyclopentadienyl imido $\beta$-hydrogen containing triethyl and tri- $n$-propyl tungsten(VI) complexes were prepared by reaction of the related trichloro derivatives $\left[\mathrm{WCp}^{\prime}\left(\mathrm{N}^{t} \mathrm{Bu}\right) \mathrm{Cl}_{3}\right]$ with three equivalents of $\mathrm{MgRCl}$
Table 2

Crystal data and structure refinement for $\mathbf{4}$

\begin{tabular}{ll}
\hline Empirical formula & $\mathrm{C}_{20} \mathrm{H}_{39} \mathrm{NW}$ \\
Formula weight & 477.37 \\
Temperature $(\mathrm{K})$ & $293(2)$ \\
Wavelength $(\AA)$ & 0.71073 \\
Crystal system & Orthorhombic \\
Space group & $P b c a$ \\
$a(\AA)$ & $11.015(1)$ \\
$b(\AA)$ & $12.928(1)$ \\
$c(\AA)$ & $28.695(1)$ \\
$V\left(\AA^{3}\right)$ & $4086.2(5)$ \\
$Z$ & 8 \\
$D$ calc. $\left(\mathrm{g}\right.$ cm $\left.{ }^{-3}\right)$ & 1.552 \\
Absorption coefficient $\left(\mathrm{mm}^{-1}\right)$ & 5.653 \\
$F(000)$ & 1920 \\
Crystal size (mm) & $0.40 \times 0.37 \times 0.30$ \\
$\theta$ range for data collection $\left({ }^{\circ}\right)$ & $2.33-26.05$ \\
Index ranges & $0<h<13,0<k<15,0<l<35$ \\
Reflections collected & 4589 \\
Independent reflections & $3999\left(R_{\text {int }}=0.0001\right)$ \\
Observed reflections $[I>2 \sigma(I)]$ & 2258 \\
Absorption correction & $\mathrm{N} / \mathrm{A}$ \\
Refinement method & Full-matrix least-squares on \\
& $F^{2}$ \\
Data/restraints/parameters & $3999 / 0 / 199$ \\
Goodness-of-fit on $F^{2}$ & 0.982 \\
Final $R$ indices $[I>2 \sigma(I)]$ & $R_{1}=0.0408, w R_{2}=0.0802$ \\
$R$ indices (all data) & $R_{1}=0.1359, w R_{2}=0.1006$ \\
Largest diff. peak and hole & 1.785 and -1.203 \\
$\quad\left(\mathrm{e} \AA^{-3}\right.$ ) & \\
\hline & \\
\hline & \\
&
\end{tabular}

( $\mathrm{R}=\mathrm{Et}, n-\mathrm{Pr})$ and were isolated as yellow crystalline solids $\left(\mathrm{Cp}^{\prime}=\eta^{5}-\mathrm{C}_{5} \mathrm{Me}_{5}\right)$ or characterized in solution $\left(\mathrm{Cp}^{\prime}=\eta^{5}-\mathrm{C}_{5} \mathrm{H}_{5}\right)$. Only the formation of the monoethyl complex [WCp* $\left(\mathrm{N}^{t} \mathrm{Bu}\right) \mathrm{Cl}_{2} \mathrm{Et}$ ] was observed by reaction with one or two equivalents of the alkylating agent, although it was not isolated free of the triethyl derivative. Thermal activation of the trialkyl compounds monitored by ${ }^{1} \mathrm{H}-\mathrm{NMR}$ spectroscopy in sealed tubes led to the formation of the alkylidene complexes $\left[\mathrm{WCp}^{\prime}\left(\mathrm{N}^{t} \mathrm{Bu}\right)(=\mathrm{CHR})\left(\mathrm{CH}_{2} \mathrm{R}\right)\right] \quad\left(\mathrm{R}=\mathrm{Me}, \mathrm{Et} ; \mathrm{Cp}^{\prime}=\eta^{5}-\right.$ $\left.\mathrm{C}_{5} \mathrm{H}_{5}, \eta^{5}-\mathrm{C}_{5} \mathrm{Me}_{5}\right)$ through $\alpha$-hydrogen elimination. This transformation is faster and more selective for $\eta^{5}-\mathrm{C}_{5} \mathrm{H}_{5}$ than for $\eta^{5}-\mathrm{C}_{5} \mathrm{Me}_{5}$-derivatives and faster for $n$-propyl than for ethyl compounds.

\section{Acknowledgements}

The authors acknowledge DGICYT (project PB970677) for financial support.

\section{References}

[1] (a) R.R. Schrock, J. Organomet. Chem. 300 (1986) 249. (b) K.J. Ivin, Olefin Methatesis, Academic Press, London, 1983. (c) R.H. Grubbs, in: G. Wilkinson (Ed.), Comprehensive Organometallics Chemistry, Pergamon Press, New York, 8 (1982) 459. (d) M. 
Leconte, J.M. Basset, F. Quignard, C. Larroche, in: P.S. Baterman (Ed.), Reactions of Coordinated Ligands. Plenum Press, New York, 1 (1986) 371.

[2] (a) G.C. Bazan, J.H. Oskam, H.-N. Cho, L.Y. Park, R.R. Schrock, J. Am. Chem. Soc. 113 (1991) 6899. (b) G.C. Bazan, R.R. Schrock, E. Khosravi, W.J. Feast, J.C. Gibson, M.B. O'Regan, J.K. Thomas, N.M. Davis, J. Am. Chem. Soc. 112 (1990) 8378 .

[3] (a) J. Belgacem, J. Kress, J.A. Osborn, J. Mol. Catal. 86 (1994) 267. (b) D.M.-T. Chan, W.C. Fultz, W.A. Nugent, D.C. Roe, T.H. Tulip, J. Am. Chem. Soc. 105 (1985) 251.

[4] (a) D.E. Wigley, Prog. Inorg. Chem. 42 (1994) 239. (b) M.L.H. Green, P.C. Konidaris, D.M. Michaelidon, P. Mountford, J. Chem. Soc. Dalton Trans. (1995) 155. (c) K. Köhler, H.W. Roesky, A. Herzog, H. Gornitza, A. Steiner, I. Uson, Inorg. Chem. 35 (1996) 1773.

[5] (a) P. Gómez-Sal, I. Jiménez, A. Martín, T. Pedraz, P. Royo, A. Selles, A. Vázquez de Miguel, Inorg. Chim. Acta 273 (1998) 270. (b) F. Amor, P. Gómez-Sal, E. de Jesús, A. Martín, A.I. Pérez, P. Royo, A. Vázquez de Miguel, Organometallics 15 (1996) 2103. (c) T. Pedraz, M.A. Pellinghelli, P. Royo, A. Tiripicchio, A. Vázquez de Miguel, J. Organomet. Chem. 534 (1997) 27.

[6] (a) R. Radius, J. Sundermeyer, Chem. Ber. 125 (1992) 2183. (b) S.R. Huber, T.C. Baldwin, D.E. Wigley, Organometallics 12 (1993) 91. (c) J. Sundermeyer, U. Radius, Ch. Burscha, Chem. Ber. 125 (1992) 2379.
[7] T.E. Glassman, H.G. Vale, R.R. Schrock, Organometallics 10 (1991) 4046.

[8] (a) L.K. Johnson, R.H. Grubbs, J.W. Ziller, J. Am. Chem. Soc. 115 (1993) 8130. (b) R.R. Schrock, R.T. DePue, J. Feldman, K.B. Yap, D.C. Yang, W.M. Davis, L. Park, M. DiMare, M. Schofield, J. Anhaus, E. Walborsky, E. Evitt, C. Kruger, P. Betz, Organometallics 9 (1990) 2262. (c) A.S. Gamble, J.M. Boncella, Organometallics 12 (1993) 2814. (d) W.M. Vaughan, K.A. Abboud, J.M. Boncella, Organometallics 14 (1995) 1567.

[9] F.J. de la Mata, J. Gómez, P. Royo, J. Organomet. Chem. 564 (1998) 277.

[10] (a) H.W. Turner, R.R. Schrock, J.D. Fellman, S.J. Holmes, J. Am. Chem. Soc. 105 (1983) 4942. (b) M.J. Burk, H.P. McGrath, R.H. Crabtree, J. Am. Chem. Soc. 110 (1988) 620. (c) R.R. Schrock, K.-Y. Shih, D.A. Dobbs, W.M. Davis, J. Am. Chem. Soc. 117 (1995) 6609. (d) J.S. Freundlich, R.R. Schrock, W.M. Davis, Organometallics 15 (1996) 2777. (e) R.R. Schrock, S.W. Seidel, N.C. Mösch-Zanetti, D.A. Dobbs, K.-Y. Shih, W.M. Davis, Organometallics 16 (1997) 5195. (f) R.R. Schrock, S.W. Seidel, N.C. Mösch-Zanetti, K.-Y. Shih, M.B. O'Donoghue, W.M. Reiff, J. Am. Chem. Soc. 119 (1997) 11876.

[11] W.A. Nugent, J. Feldman, J.C. Calabrese, J. Am. Chem. Soc. 117 (1995) 8992.

[12] G.M. Sheldrick, SHELXL 97, University of Gottingen, Gottingen, Germany, 1997. 